\title{
Apoptotic Genes' Expression in an Ovarian Cancer Cell Line (A2780) Exposed to Green Synthesized Cerium Oxide Nanoemulsion
}

\author{
Mohammad Ashna $^{1}{ }^{\circledR}$, Ali Es-haghi ${ }^{1 *(\infty}$, Mojgan Soltani ${ }^{1}$ \\ 'Department of Biology, Mashhad Branch, Islamic Azad University, Mashhad, Iran
}

\author{
*Correspondence to \\ Ali Es-haghi (PhD), \\ Department of Biology, Mashhad \\ Branch, Islamic Azad University, \\ Mashhad, Iran, \\ Email: ashaghi@gmail.com
}

Received January 21, 2021 Accepted May 24, 2021 Published online June 30, 2021

Please cite this article as follows: Ashna $M$, Es-haghi A, Soltani M. Apoptotic genes' expression in an ovarian cancer cell line (A2870) exposed to green synthesized cerium oxide nanoemulsion. Int J Basic Sci Med. 2021;6(2):51 -

56. doi:10.34172/ ijbms.2021.09.

\begin{abstract}
Introduction: Cancer can be defined as an illness of reformed gene expression. There are numerous agents affecting gene expression and altering cellular activities. Nanotechnology has offered the possibility of modulating tumor suppressor genes' expression, improving kinetics of gene-targeted therapeutics, and simplifying drug delivery to tumors and across bio-complexes. Methods: Gene expressions of caspase 3, 8 and 9, Bax and Bcl2 were assessed after RNA extraction and cDNA synthesis by real-time polymerase chain reaction (PCR) in an ovarian cancerous cell line (A2780). Real-time PCR was employed to determine the change fold of apoptotic genes in the cells exposed to the biosynthesized $\mathrm{CeO}_{2}-\mathrm{NPs}$ (cerium oxide nanoparticles) at the dose of 0 , 7,9 , and $11 \mu \mathrm{g} / \mathrm{mL}$ after 24 hours of incubation.

Results: Our findings displayed a significant increase in the antioxidant genes' expression in the A2870 cells. The results exhibited that the biosynthesized $\mathrm{CeO}_{2}-\mathrm{NPs}$ could enhance the Bax/ $\mathrm{Bcl} 2$ ratio in a dose-dependent way. Also, the expression of caspase3, 8, and 9 up-regulated significantly under the dose of $11 \mu \mathrm{g} / \mathrm{mL}$.

Conclusion: Considering the effects of the bio-fabricated $\mathrm{CeO}_{2}-\mathrm{NPs}_{\mathrm{s}}$ on the expression of apoptotic genes in ovarian cancerous cell lines, these nanoparticles (NPs) may be employed in pharmacology to develop new anti-cancer medications.

Keywords: Cerium oxide nanoemulsion, Apoptotic gene, Ovarian cancer, A2780 cell line
\end{abstract}

\section{Introduction}

Nanotechnology is known as a novel method for cancer therapy and is quickly expanding its therapeutic applications..$^{1-3}$ Nano-based materials, which have exclusive features, are being extensively employed in biomedical studies. ${ }^{4-6}$ Quick progresses in nanoparticles (NPs) have greatly influenced cancer identification and treatment. ${ }^{7,8}$ One of these nanomaterials is nanoceria (i.e., cerium oxide NPs). Nanoceria is widely employed in engineering as a catalyst, ${ }^{9}$ sensor, ${ }^{10}$ opticalsensing agent, ${ }^{11}$ or UV-absorber, ${ }^{12}$ as well as in fuel cells. ${ }^{13}$ Nanoceria could decrease ROS (reactive oxygen species) in cells ${ }^{14}$, 15 and alleviate intracellular free radicals levels. ${ }^{16,17} \mathrm{~A}$ number of studies indicated that the antioxidant properties of nanoceria could be employed for managing illnesses like diabetes, ${ }^{18}$ chronic inflammation, ${ }^{19}$ neurological diseases, ${ }^{20}$ and cancer. ${ }^{21}$ There are several reports noting that $\mathrm{CeO}_{2} \mathrm{NPs}$ (cerium oxide nanoparticles) care cells for oxidative stress-caused apoptosis. ${ }^{22-24}$

The antioxidants such as phenols, flavonoids, anthocyanins, and reducing sugars which are present in plants can be effective in treating and preventing the progression of numerous infections. ${ }^{25-28}$ Thus, medicinal plants are widely under study because of their antioxidant materials and nutrient preservatives. ${ }^{29-32}$

Bio-indicators can now be used to characterize toxicity or cancer. ${ }^{33,34}$ Many studies have shown that nanotechnology provides a good alternative for cancer treatment. ${ }^{35}$ Cerium has been developed for medicinal uses, presenting roles as antioxidants in bio-systems. Accordingly, cerium NPs seem to be well-suited for nano-medicine applications. ${ }^{36}$ Cerium oxide has been described to have beneficial properties, for instance low toxicity, large

(c) 2021 The Author(s); Published by Zabol University of Medical Sciences. This is an open-access article distributed under the terms of the Creative Commons Attribution License (http://creativecommons.org/licenses/by/4.0), which permits unrestricted use, distribution, and reproduction in any medium, provided the original work is properly cited. 
surface area, and good bio-compatibility.

There are many methods for nanoparticle synthesis, among which green methods applying plants are more important because of their low toxicity, high safety, and being eco-friendly. Extracts from several plants such Ribes khorasanicum, ${ }^{37}$ Handelia trichophylla, ${ }^{38}$ Tribulus terrestris ${ }^{39}$ and other herbal species have been used for the synthesis of NPs. Brassica napus from the Brassicaceae family is an important plant in the food and agriculture industries. The oil of canola (B. napus), as an important major oilseed crop, is used in many food products.

Nanoemulsions are sub-micron-sized emulsions used to deliver drugs to cancer cells and have been extensively considered in recent years. Ovarian cancer is the seventh frequently identified cancer among women. ${ }^{40}$ Rare studies have been performed on the effects of cerium nanoemulsions on cancer cells. This investigation aimed to estimate the gene expression of a number of apoptotic genes in the A2780 cell line exposed to various concentrations of cerium oxide nanoemulsions.

\section{Materials and Methods}

Experimental Materials

PCR Master Mix, SYBR Green PCR Master Mix, and cDNA synthesis Kit were obtained by Qiagen (Germany).

\section{Extraction and Preparation of Cerium Oxide Nanoemulsions}

With the purpose of providing the extract, $10 \mathrm{~g}$ of $B$. napus pollen grains powder was added to distilled water and mixed. The combination was heated for 60 minutes at $40^{\circ} \mathrm{C}$ and then filtered. The $\mathrm{Ce}(\mathrm{NO} 3)_{3} \cdot 6 \mathrm{H}_{2} \mathrm{O}$ solution in $90 \mathrm{~mL}$ distilled water and $10 \mathrm{~mL}$ pollen extract was stirred for 2 hours at $40^{\circ} \mathrm{C}$. Subsequently, the precipitate was separated and heated at $500^{\circ} \mathrm{C}$ for 2 hours to obtain the nanoceria. Since cerium oxide NPs are insoluble in water, its use is somehow limited in various fields. In order to increase their bioavailability, nanoemulsions were formed from cerium oxide NPs. To prepare the nanoemulsions, 5 $\mathrm{mg}$ of the NPs was suspended in polysorbate (tween) 20 $(100 \mu \mathrm{L})$ and tween $80(100 \mu \mathrm{L})$ and then added to $500 \mu \mathrm{L}$ of ethylene glycol and completely mixed. Finally, it was reached to $50 \mathrm{~mL}$ by adding distilled water. ${ }^{15}$

\section{Cell Culture}

A2780, the human ovarian cancer cell line, was obtained from National Pasteur Institute (Iran) and maintained in DMEM medium. Cells were cultured, and $\sim 1 \times 10^{4}$ cells/ well were planted into 96-well dishes. ${ }^{41}$ A2780 cells were treated with the bio-fabricated $\mathrm{CeO}_{2} \mathrm{NPs}$ to check their cytotoxicity.

\section{Expression of Apoptotic Genes}

The gene expressions of caspase 3, 8, and 9, $\mathrm{Bcl} 2$, and Bax were determined in the ovarian cancer cells (A2780) treated with the fabricated NPs. The cells were seeded at $5 \times 10^{3}$ cells $/ \mathrm{mL}$ concentration in RMPI 1640 containing fetal bovine serum (FBS) and Pen-Strep. After that, the cells were treated with $0,7,9$, and $11 \mu \mathrm{g} / \mathrm{mL}$ concentrations of the NPs for 48 hours. Then the treated cells were washed by Phosphate Buffered Saline (PBS). The gene expressions of caspase 3, 8, and 9, $\mathrm{Bcl} 2$, and Bax were evaluated by quantitative reverse transcription real time polymerase chain reaction (RT-qPCR) and the primers displayed in Table 1.

\section{RNA Extraction}

After 48 hours of treatment with $\mathrm{CeO}_{2} \mathrm{NPs}$, total RNA was obtained from A2780 cells. For this, one mL of the RNXplus solution was added to cells. Later, chloroform was added, and centrifuge was performed at $4^{\circ} \mathrm{C}$ to extract RNA, which was quantified by a plate-reader (Epoch, Biotek, Winooski, VT, UK).

\section{cDNA Synthesis}

cDNA was produced from the total extracted RNA by Fermentase Kit (Germany). The mixture was kept for one cycle at $37^{\circ} \mathrm{C} / 15 \mathrm{~min}$, one cycle at $85^{\circ} \mathrm{C} / 5$ seconds, and one cycle at $4^{\circ} \mathrm{C} / 5 \mathrm{~min}$. Furthermore, RT-enzyme-free samples were applied to detect pollution of samples.

\section{Real-Time Polymerase Chain Reaction}

The expression of apoptotic genes was evaluated. Thermal program was set as a primary step $\left(95^{\circ} \mathrm{C} / 2\right.$ min) subsequently 30 cycles $\left(95^{\circ} \mathrm{C} / 15 \mathrm{~s} ; 56.4^{\circ} \mathrm{C} / 20 \mathrm{~s}\right.$, and $72^{\circ} \mathrm{C} / 30 \mathrm{~s}$ ). GAPDH (glyceraldehyde 3-phosphate dehydrogenase) was employed as the reference gene. Deionized water was used as the negative control.

\section{Results}

In this research, a human ovarian cancer cell line (A2780) was used to test the effects of biosynthesized $\mathrm{CeO}_{2} \mathrm{NPs}$ on

Table 1. Primers Employed for Gene Expression Examination

\begin{tabular}{lcc}
\hline Genes & Forward & Reverse \\
\hline Bax & TTTGCTTCAGGGTTTCATCCA & CTCCATGTTACTGTCCAGTTCGT \\
Bcl-2 & CATGTGTGTGGAGAGCGTCAAC & CAGATAGGCACCCAGGGTGAT \\
Caspase-3 & CTGGACTGTGGCATTGAGAC & ACAAAGCGACTGGATGAACC \\
Caspase-8 & GAAAAGCAAACCTCGGGGATAC & CCAAGTGTGTTCCATTCCTGTC \\
Caspase-9 & AGTTCCCGGGTGCTGTCTAT & GCCATGGTCTTTCTGCTCAC \\
GAPDH & TGCTGGTGCTGAGTATGTCG & GCATGTCAGATCCACAACGG \\
\hline
\end{tabular}


the expression of apoptosis-related genes (bax, bcl2, and a number of caspases). The gene expression of the caspases, $\mathrm{Bcl} 2$, and Bax upregulated in the cancerous cells exposed to the various concentrations $(7,9$, and $11 \mu \mathrm{g} / \mathrm{mL})$ of the prepared $\mathrm{CeO}_{2}$-NPs. The fold-change of Caspase- 3 treated with $11 \mu \mathrm{g} / \mathrm{mL}$ of $\mathrm{CeO}_{2}-\mathrm{NPs}$ was meaningful $(P<0.001)$ compared to non-treated cells (Figure 1$)$. Also, an increase in the expressions of caspase 8 and caspase 9 was observed upon treatment with the synthesized cerium oxide nanoemulsions (Figures 2 and 3).

Our results also demonstrated that the biosynthesized $\mathrm{CeO}_{2} \mathrm{NPs}$ could raise the $\mathrm{Bax} / \mathrm{Bcl} 2$ ratio in a dosagedependent manner (Figures 4 and 5).

\section{Discussion}

This study aimed to produce cerium oxide nanoemulsions and characterize their biological features, with a special focus on the applications of cerium oxide nanoemulsions as anti-tumor cytotoxic agents. Natural materials and their derivatives are safer than artificial materials and drugs to be used to generate biologically applicable therapeutics. ${ }^{42}$ Medicinal plants have efficient biological complexes in their construction, which work as reducing factors during the synthesis process of nanomaterials. ${ }^{43,44}$ Brassica napus $\mathrm{L}$. is one of the important natural herbs with cytotoxicity

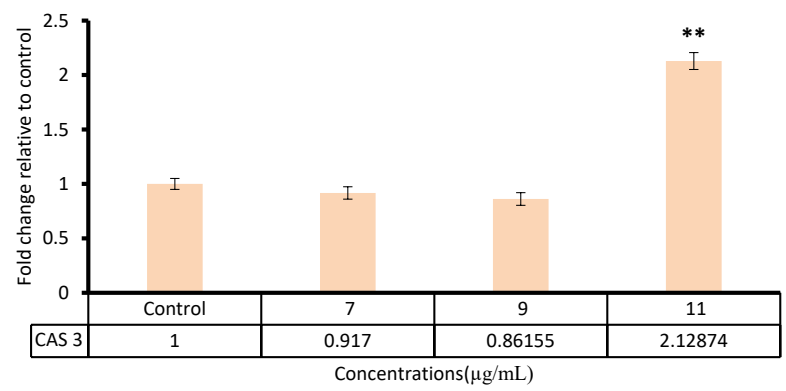

Figure 1. The Gene Expression Study of Caspase-3 Gene in the A2780 Cancerous Cells Treated With the NPs at 7, 9, and $11 \mu \mathrm{g} / \mathrm{mL}$ Concentrations. ${ }^{* *} P<0.001$; significant difference as compared to the control (untreated).

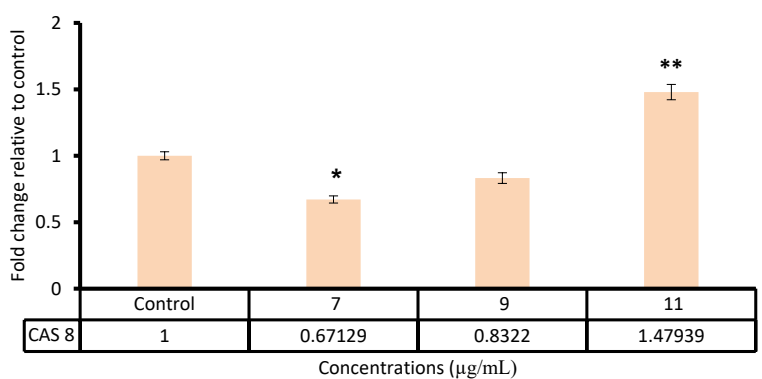

Figure 2. The Gene Expression Analysis of Caspase-8 in the A2780 Cancerous Cells Treated With 7, 9, and $11 \mu \mathrm{g} / \mathrm{mL}$ Concentrations of the NPs. The experiment was done in triplicate. ${ }^{*} P<0.05$; a significant difference as compared to the control. ${ }^{* * P}<0.01$; a significant difference in comparison to the control cells (untreated).

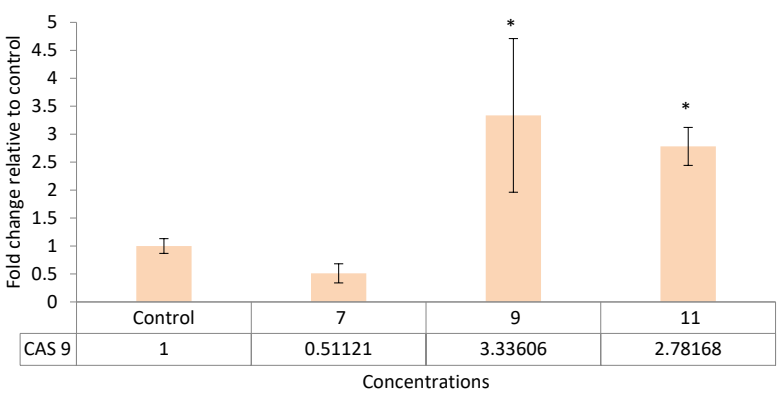

Figure 3. Gene Expression Analysis of Caspase- 9 in the $A 2780$ Cancerous Cells Treated With 7, 9, and $11 \mu \mathrm{g} / \mathrm{mL}$ Concentrations of the NPs. ${ }^{*} P<0.05$ shows a significant difference in comparison to the control cells (untreated).

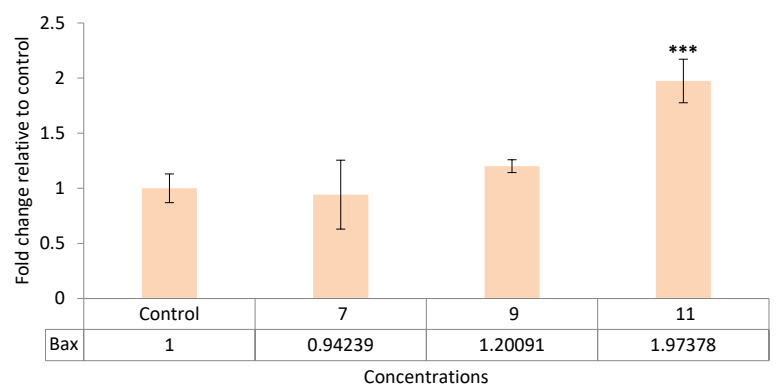

Figure 4. Gene Expression Examination of Bax in the A2780 Cancerous Cells Treated With 7, 9, and $11 \mu \mathrm{g} / \mathrm{mL}$ of $\mathrm{CeO}_{2}-\mathrm{NPs}$. ${ }^{* * *} P<0.001$ indicates a significant difference in comparison to the control cells (untreated)

against different types of tumor cells. In this study, the green-synthesized $\mathrm{CeO}_{2}$-NPs produced from $B$. napus $\mathrm{L}$. revealed high anticancer activity. Regarding the enormous biomedical and anti-cancer activities of NPs, $\mathrm{CeO}_{2}$ NPs have been suggested as anticancer agents in many investigations. ${ }^{45}$ The anti-proliferative effect has been noted as one of the anticancer mechanisms attributed to cell cycle and apoptosis induction in cancer cells. ${ }^{46} \mathrm{We}$ here showed that the $\mathrm{CeO}_{2}$-NPs significantly modulated the expressions of apoptotic genes in the cancerous A2780 cell line, as shown by RT-PCR. Among the key agents contributing to apoptosis regulation is $\mathrm{Bcl}-2$, as well as other processes such as cytochrome $\mathrm{C}$ and caspase- 9 activation.

The ratio of $\mathrm{bax} / \mathrm{bcl} 2$ expression governs the progression of apoptosis and therefore can influence cancer development. ${ }^{47,48}$ Caspase 3 and caspase 9 are two important players in the progression of intrinsic and extrinsic apoptotic routes, respectively. ${ }^{49}$ Our results here were in accordance with prior studies indicating the bax/ bcl 2 ratio as an indicator for cancer progression. ${ }^{50,51}$ In the present research, the prepared $\mathrm{CeO}_{2}-\mathrm{NPs}$ up-regulated caspase 3 and 9 expressions, inhibiting the proliferation of A2780 cells. This suggested that the apoptotic path stimulated by bax/bcl 2 and caspase 3 could participate 


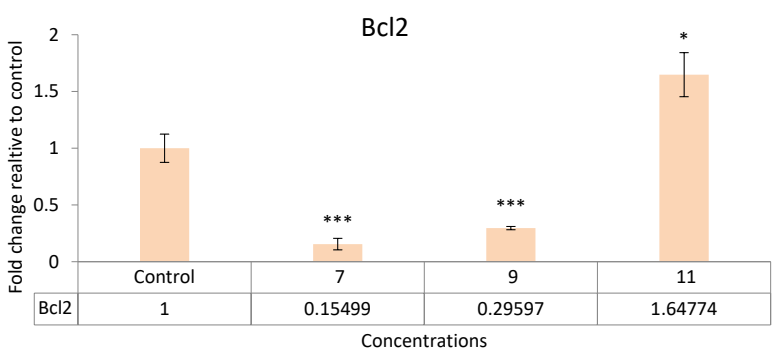

Figure 5. The Gene Expression Examination of $\mathrm{Bcl} 2$ Gene in the A2780 Cancerous Cells Treated With the 7, 9, and $11 \mu \mathrm{g} / \mathrm{mL}$ Concentrations of $\mathrm{CeO}_{2}$-NPs. ${ }^{*} P<0.05$ and ${ }^{* * *} \mathrm{P}<0.001$ reveal significant differences in comparison to the control cells (untreated).

roles in apoptosis induction in cancer cells. Caspase 3, a main indicator of apoptosis, was linked with reduced $\mathrm{bcl} 2 / \mathrm{bax}$ ratio accompanied with the stimulation of and a noteworthy rise in caspase 9 expression, indicating apoptosis induction.

\section{Conclusion}

In this investigation, the expression of apoptosis-related genes was investigated in the A2780 ovarian cancerous cell line exposed to biosynthesized $\mathrm{CeO}_{2}$-NPs. The produced NPs enhanced the expression of caspase 3, 8, and 9 and upregulated the $\mathrm{Bax} / \mathrm{Bcl} 2$ ratio in the assessed cancerous cells. Therefore, these NPs can have therapeutic potential for treating disorders such as cancer.

\section{Author contribution}

MA designed and performed experiments, MS analyzed data and $\mathrm{AE}$ wrote the paper and supervisor of research.

Ethical Approval

Not applicable.

\section{Competing Interests}

There is no conflict of interest to declare.

\section{Acknowledgment}

Dr. Es-haghi gratefully thanks the Branch of Mashhad, Islamic Azad University, for support.

\section{References}

1. Taghavizadeh Yazdi ME, Darroudi M, Amiri MS, et al. Anticancer, antimicrobial, and dye degradation activity of biosynthesised silver nanoparticle using Artemisia kopetdaghensis. Micro Nano Lett. 2020;15(14):1046-1050. doi:10.1049/mnl.2020.0387

2. Taghavizadeh Yazdi ME, Nourbakhsh F, Mashreghi $\mathrm{M}$, Mousavi SH. Ultrasound-based synthesis of $\mathrm{ZnO}$. $\mathrm{Ag} 2 \mathrm{O} 3$ nanocomposite: characterization and evaluation of its antimicrobial and anticancer properties. Res Chem Intermed. 2021;47(3):1285-1296. doi:10.1007/s11164-02004355-w

3. Shamasi Z, Es-Haghi A, Taghavizadeh Yazdi ME, Amiri MS, Homayouni-Tabrizi M. Role of Rubia tinctorum in the synthesis of zinc oxide nanoparticles and apoptosis induction in breast cancer cell line. Nanomed J. 2021;8(1):65-72. doi:10.22038/nmj.2021.08.07

4. Rezaei MR, Es-Haghi A, Yaghmaei P, Ghobeh M. Biological fabrication of $\mathrm{Ag} / \mathrm{Ag} 2 \mathrm{O}$ nanoparticles by Haplophyllum obtusifolium watery extract: characterisation and estimation of its biochemical activities. Micro Nano Lett. 2020;15(13):898-902. doi:10.1049/mnl.2020.0269

5. Es-Haghi A, Soltani M, Karimi E, Namvar F, HomayouniTabrizi M. Evaluation of antioxidant and anticancer properties of zinc oxide nanoparticles synthesized using Aspergillus niger extract. Mater Res Express. 2019;6(12):125415. doi:10.1088/2053-1591/ab5f72

6. Hashemzadeh MR, Taghavizadeh Yazdi ME, Amiri MS, Mousavi SH. Stem cell therapy in the heart: biomaterials as a key route. Tissue Cell. 2021;71:101504. doi:10.1016/j. tice.2021.101504

7. Es-Haghi A, Javadi F, Taghavizadeh Yazdi ME, Amiri MS. The expression of antioxidant genes and cytotoxicity of biosynthesized cerium oxide nanoparticles against hepatic carcinoma cell line. Avicenna J Med Biochem. 2019;7(1):1620. doi:10.34172/ajmb.2019.04

8. Amiri MS, Mohammadzadeh V, Taghavizadeh Yazdi ME, Barani M, Rahdar A, Kyzas GZ. Plant-based gums and mucilages applications in pharmacology and nanomedicine: a review. Molecules. 2021;26(6):1770. doi:10.3390/molecules 26061770

9. Zhang Z, Li R, Wang M, et al. Two steps synthesis of CeTiOx oxides nanotube catalyst: enhanced activity, resistance of $\mathrm{SO} 2$ and $\mathrm{H} 2 \mathrm{O}$ for low temperature NH3-SCR of NOx. Appl Catal B Environ. 2021;282:119542. doi:10.1016/j. apcatb.2020.119542

10. Wang T, Liu T, Li W, et al. Triethylamine sensing with a mixed potential sensor based on $\mathrm{Ce} 0.8 \mathrm{Gd} 0.2 \mathrm{O} 1.95$ solid electrolyte and La1-xSrxMnO3 $(\mathrm{x}=0.1,0.2,0.3)$ sensing electrodes. Sens Actuators B Chem. 2021;327:128830. doi:10.1016/j.snb.2020.128830

11. Vigneselvan S, Manikandan V, Petrila I, Vanitha A, Chandrasekaran J. Effect of copper substitution on structural, optical and humidity-sensing characteristics of cerium oxide nanoparticles. J Phys Chem Solids. 2020;136:109173. doi:10.1016/j.jpcs.2019.109173

12. Lu L, Dai G, Yan L, et al. In-situ low-temperature sol-gel growth of nano-cerium oxide ternary composite films for ultraviolet blocking. Opt Mater. 2020;101:109724. doi:10.1016/j.optmat.2020.109724

13. Seo DC, Jeon I, Jeong ES, Jho JY. Mechanical properties and chemical durability of nafion/sulfonated graphene oxide/cerium oxide composite membranes for fuel-cell applications. Polymers (Basel). 2020;12(6). doi:10.3390/ polym 12061375

14. Es-Haghi A, Aseyd Nezhad S. The anti-oxidant and antiinflammatory properties of cerium oxide nanoparticles synthesized using Origanum majorana L. leaf extract. Int J Basic Sci Med. 2019;4(3):108-112. doi:10.15171/ ijbsm.2019.20

15. Ashna M, Es-Haghi A, Karimi Noghondar M, Al Amara D, Taghavizadeh Yazdi ME. Greener synthesis of cerium oxide nanoemulsion using pollen grains of Brassica napus and evaluation of its antitumour and cytotoxicity properties. 
Mater Technol. 2020:1-8. doi:10.1080/10667857.2020.186 3558

16. Singh KR, Nayak V, Sarkar T, Singh RP. Cerium oxide nanoparticles: properties, biosynthesis and biomedical application. RSC Adv. 2020;10(45):27194-27214. doi:10.1039/d0ra04736h

17. Dulany K, Hepburn K, Goins A, Allen JB. In vitro and in vivo biocompatibility assessment of free radical scavenging nanocomposite scaffolds for bone tissue regeneration. J Biomed Mater Res A. 2020;108(2):301-315. doi:10.1002/ jbm.a.36816

18. Augustine R, Zahid AA, Hasan A, Dalvi YB, Jacob J. Cerium oxide nanoparticle-loaded gelatin methacryloyl hydrogel wound-healing patch with free radical scavenging activity. ACS Biomater Sci Eng. 2021;7(1):279-290. doi:10.1021/ acsbiomaterials.0c01138

19. Adebayo OA, Akinloye O, Adaramoye OA. Cerium oxide nanoparticles attenuate oxidative stress and inflammation in the liver of diethylnitrosamine-treated mice. Biol Trace Elem Res. 2020;193(1):214-225. doi:10.1007/s12011-01901696-5

20. Soluki M, Mahmoudi F, Abdolmaleki A, Asadi A, Sabahi Namini A. Cerium oxide nanoparticles as a new neuroprotective agent to promote functional recovery in a rat model of sciatic nerve crush injury. Br J Neurosurg. 2020:1-6. doi:10.1080/02688697.2020.1864292

21. Aseyd Nezhad S, Es-Haghi A, Homayouni-Tabrizi M. Green synthesis of cerium oxide nanoparticle using Origanum majorana L. leaf extract, its characterization and biological activities. Appl Organomet Chem. 2020;34(2):e5314. doi:10.1002/aoc.5314

22. Chen S, Hou Y, Cheng G, Zhang C, Wang S, Zhang J. Cerium oxide nanoparticles protect endothelial cells from apoptosis induced by oxidative stress. Biol Trace Elem Res. 2013;154(1):156-166. doi:10.1007/s12011-013-9678-8

23. Datta A, Mishra S, Manna K, Saha KD, Mukherjee S, Roy S. Pro-oxidant therapeutic activities of cerium oxide nanoparticles in colorectal carcinoma cells. ACS Omega. 2020;5(17):9714-9723. doi:10.1021/acsomega.9b04006

24. Pesaraklou A, Matin MM. Cerium oxide nanoparticles and their importance in cell signaling pathways for predicting cellular behavior. Nanomedicine (Lond). 2020;15(17):17091718. doi:10.2217/nnm-2020-0104

25. Modarres M, Esmaeilzadeh Bahabadi S, Taghavizadeh Yazdi ME. Enhanced production of phenolic acids in cell suspension culture of Salvia leriifolia Benth. using growth regulators and sucrose. Cytotechnology. 2018;70(2):741750. doi:10.1007/s10616-017-0178-0

26. Taghavizadeh Yazdi ME, Amiri MS, Akbari S, et al. Green synthesis of silver nanoparticles using Helichrysum graveolens for biomedical applications and wastewater treatment. Bionanoscience. 2020;10(4):1121-1127. doi:10.1007/s12668-020-00794-2

27. Taghavizadeh Yazdi ME, Modarres M, Amiri MS, Darroudi M. Phyto-synthesis of silver nanoparticles using aerial extract of Salvia leriifolia Benth and evaluation of their antibacterial and photo-catalytic properties. Res Chem Intermed. 2019;45(3):1105-1116. doi:10.1007/s11164-0183666-8

28. Darroudi M, Taghavizadeh Yazdi ME, Amiri MS. Plant- mediated biosynthesis of nanoparticles. In: 21st Century Nanoscience-A Handbook. CRC Press; 2020:1-18.

29. Amiri MS, Joharchi MR, Taghavizadehyazdi ME. Ethnomedicinal plants used to cure jaundice by traditional healers of mashhad, iran. Iran J Pharm Res. 2014;13(1):157-162.

30. Rezaei MR, Es-Haghi A, Yaghmaei P, Ghobeh M. Assessment of antioxidant and antimicrobial activities of silver nanoparticles biosynthesized by Haplophyllum obtusifolium. Avicenna J Med Biochem. 2020;8(2):94-98. doi:10.34172/ajmb.2020.14

31. Modarres M, Taghavizadeh Yazdi ME. Elicitation improves phenolic acid content and antioxidant enzymes activity in Salvia leriifolia cell cultures. Iran J Sci Technol Trans A Sci. 2021;45(3):849-855. doi:10.1007/s40995-021-01070-y

32. Taghavizadeh Yazdi ME, Nazarnezhad S, Mousavi SH, et al. Gum Tragacanth (GT): a versatile biocompatible material beyond borders. Molecules. 2021;26(6). doi:10.3390/ molecules 26061510

33. Taghavizadeh Yazdi ME, Amiri MS, Nourbakhsh F, Rahnama M, Forouzanfar F, Mousavi SH. Bio-indicators in cadmium toxicity: role of HSP27 and HSP70. Environ Sci Pollut Res. 2021;28(21):26359-26379. doi:10.1007/s11356021-13687-y

34. Zou Y, Li M, Xing Y, Duan T, Zhou X, Yu F. Bioimaging of glutathione with a two-photon fluorescent probe and its potential application for surgery guide in laryngeal cancer. ACS Sens. 2020;5(1):242-249. doi:10.1021/ acssensors.9b02118

35. Baghani M, Es-Haghi A. The antioxidant activity and cytotoxic effects of Amaranthus cruentus-biosynthesized silver nanoparticles toward MCF-7 breast cancer cell line. Int J Basic Sci Med. 2019;4(1):17-22. doi:10.15171/ ijbsm.2019.04

36. Jain A, Behera $M$, Mahapatra C, Sundaresan NR, Chatterjee K. Nanostructured polymer scaffold decorated with cerium oxide nanoparticles toward engineering an antioxidant and anti-hypertrophic cardiac patch. Mater Sci Eng C Mater Biol Appl. 2021;118:111416. doi:10.1016/j. msec.2020.111416

37. Taghavizadeh Yazdi ME, Khara J, Housaindokht MR, et al. Role of Ribes khorassanicum in the biosynthesis of AgNPs and their antibacterial properties. IET Nanobiotechnol. 2019;13(2):189-192. doi:10.1049/iet-nbt.2018.5215

38. Taghavizadeh Yazdi ME, Amiri MS, Hosseini HA, et al. Plant-based synthesis of silver nanoparticles in Handelia trichophylla and their biological activities. Bull Mater Sci. 2019;42(4):155. doi:10.1007/s12034-019-1855-8

39. Hamidi A, Taghavizadeh Yazdi ME, Amiri MS, Hosseini HA, Darroudi M. Biological synthesis of silver nanoparticles in Tribulus terrestris L. extract and evaluation of their photocatalyst, antibacterial, and cytotoxicity effects. Res Chem Intermed. 2019;45(5):2915-2925. doi:10.1007/ s11164-019-03770-y

40. Reid BM, Permuth JB, Sellers TA. Epidemiology of ovarian cancer: a review. Cancer Biol Med. 2017;14(1):9-32. doi:10.20892/j.issn.2095-3941.2016.0084

41. Arazmjoo S, Es-Haghi A, Mahmoodzadeh H. Evaluation of anti-cancer and antioxidant properties of nanoemulsions synthesized by Nigella sativa L. tincture. Nanomed J. 2021;8(1):57-64. doi:10.22038/nmj.2021.08.06 
42. Taghavizadeh Yazdi ME, Khara J, Sadeghnia HR, Esmaeilzadeh Bahabadi S, Darroudi M. Biosynthesis, characterization, and antibacterial activity of silver nanoparticles using Rheum turkestanicum shoots extract. Res Chem Intermed. 2018;44(2):1325-1334. doi:10.1007/ s11164-017-3169-z

43. Taghavizadeh Yazdi ME, Khara J, Housaindokht MR, et al. Biocomponents and antioxidant activity of Ribes khorasanicum. Int J Basic Sci Med. 2018;3(3):99-103. doi:10.15171/ijbsm.2018.18

44. Taghavizadeh Yazdi ME, Housaindokht MR, Sadeghnia HR, Esmaeilzadeh Bahabadi S, Amiri MS, Darroudi M. Assessment of phytochemical components and antioxidant activity of Rheum turkestanicum Janisch. Stud Med Sci. 2020;31(2):75-81.

45. Javadi F, Taghavizadeh Yazdi ME, Baghani M, EsHaghi A. Biosynthesis, characterization of cerium oxide nanoparticles using Ceratonia siliqua and evaluation of antioxidant and cytotoxicity activities. Mater Res Express. 2019;6(6):065408. doi:10.1088/2053-1591/ab08ff

46. Mousavi-Kouhi SM, Beyk-Khormizi A, Amiri MS, Mashreghi M, Taghavizadeh Yazdi ME. Silver-zinc oxide nanocomposite: from synthesis to antimicrobial and anticancer properties. Ceram Int. 2021;47(15):2149021497. doi:10.1016/j.ceramint.2021.04.160

47. Kieber JJ, Rothenberg M, Roman G, Feldmann KA, Ecker JR. CTR1, a negative regulator of the ethylene response pathway in Arabidopsis, encodes a member of the raf family of protein kinases. Cell. 1993;72(3):427-441. doi:10.1016/0092-8674(93)90119-b

48. Yang E, Korsmeyer SJ. Molecular thanatopsis: a discourse on the BCL2 family and cell death. Blood. 1996;88(2):386401.

49. Liu DL, Bu H, Li H, et al. Emodin reverses gemcitabine resistance in pancreatic cancer cells via the mitochondrial apoptosis pathway in vitro. Int J Oncol. 2012;40(4):10491057. doi:10.3892/ijo.2011.1285

50. Ahmadi S, Ghollasi M, Mahmoodzadeh Hosseini H. The apoptotic impact of nisin as a potent bacteriocin on the colon cancer cells. Microb Pathog. 2017;111:193-197. doi:10.1016/j.micpath.2017.08.037

51. Azimian H, Dayyani M, Bahreyni Toossi MT, Mahmoudi M. Bax/Bcl-2 expression ratio in prediction of response to breast cancer radiotherapy. Iran J Basic Med Sci. 2018;21(3):325-332. doi:10.22038/ijbms.2018.26179.6429 